\title{
An intersectional gender analysis in kidney transplantation: women who donate a kidney
}

Laura Rota-Musoll $^{1,2}$, Serena Brigidi ${ }^{3^{*}}$, Esmeralda Molina-Robles ${ }^{1,2}$, Ester Oriol-Vila ${ }^{1,2}$, Laureano Perez-Oller ${ }^{1}$ and Mireia Subirana-Casacuberta ${ }^{2,4}$

\begin{abstract}
Background: Living-donor transplantation is the best treatment option in patients with chronic kidney failure. Global data show that women are less likely to be kidney recipients than men but are more likely to become living kidney donors. We explored the experience of women who donate a kidney to relatives with biological and sociocultural ties and to understand the similarities and differences in their experience.

Methods: A qualitative hermeneutic phenomenological study with an intersectional analysis of gender. Ten women donors accepted in the transplant evaluation period participated, all of whom donated a kidney to a pre-dialysis relative. Two categories were included: women with biological kinship ties (mothers, sisters) and women who have a socio-cultural relationship (wives) with kidney recipient. The data were collected through semi-structured in-depth interviews and analysed using thematic analysis.

Results: Women donate their kidneys in a convinced manner, without worrying about their health, with an optimistic and positive attitude, and without believing that they are acting heroically. Women with biological kinship ties see it as a 'naturalization thing'. In contrast, wives donate conditioned by gender roles, but also as a form of empowerment and as a personal benefit: they donate in order to avoid taking on carer role for their husband and as a way of protecting their children.

Conclusion: The study's findings expand the conception of kidney donation as solely altruistic and may help professionals to pay attention to the complexity and intersectionality of features present in women who are living kidney donors.
\end{abstract}

Keywords: Gender, Intersectionality, Kidney donor, Living donor transplantation, Qualitative methodology

\section{Introduction}

According to the literature, the population with endstage-renal disease (ESRD) that needs renal replacement therapy (RRT) is increasing [1]. Further, access to this therapy is uneven depending on the region, with only $50 \%$ of those who need RRT receiving treatment [2].

\footnotetext{
* Correspondence: serena.brigidi@gmail.com

${ }^{3}$ Department of Anthropology, Philosophy and Social Work in the University of Rovira i Virgili (URV), Tarragona, Catalunya, Spain

Full list of author information is available at the end of the article
}

Living-donor kidney transplantation is the best treatment option for survival and quality of life outcomes of patient with kidney disease [3]. In 2017, 36\% of kidney transplants worldwide were from living donors [4]. Kidney donation is considered a safe procedure, although there are risks in the perioperative process [5] and studies have shown that donors have a slightly higher risk of cardiovascular and long-term kidney disease than the healthy population [6-8]. In general, living kidney donors have psychosocial outcomes like quality of life that

(C) The Author(s). 2021 Open Access This article is licensed under a Creative Commons Attribution 4.0 International License, which permits use, sharing, adaptation, distribution and reproduction in any medium or format, as long as you give appropriate credit to the original author(s) and the source, provide a link to the Creative Commons licence, and indicate if changes were made. The images or other third party material in this article are included in the article's Creative Commons licence, unless indicated otherwise in a credit line to the material. If material is not included in the article's Creative Commons licence and your intended use is not permitted by statutory regulation or exceeds the permitted use, you will need to obtain permission directly from the copyright holder. To view a copy of this licence, visit http://creativecommons.org/licenses/by/4.0/. The Creative Commons Public Domain Dedication waiver (http://creativecommons.org/publicdomain/zero/1.0/) applies to the data made available in this article, unless otherwise stated in a credit line to the data. 
are the same or better after the donation and in comparison with non-donors [5]. Living donor may have to bear a financial burden (uncovered financial expenses and lost salary) $[9,10]$ and difficulty organising their life during the donation period [11].

Chronic kidney disease shows differences between men and women in prevalence [12] and rate of progression [13, 14]. However, in different parts of the world there is unequal access to and possibilities for renal replacement treatment between men and women $[15,16]$. There are also differences in access to kidney transplantation. Women are less likely than men to receive a cadaveric kidney transplant [17]. In some cases, women had discussions, on fewer occasions than men, with health professionals about kidney transplantation as a therapeutic option [18]. In others, testing was finished too late to be included in the cadaver donor list [19].

Regarding living-donor kidney transplantation, gender disparity is very clear: women donate more kidneys than they receive $[14,20,21]$. Official global data show that 6 out of every 10 kidney donors are women [22].

\section{Literature review}

Kidney donation has gender. Several studies show that gender inequality in transplants favours men, while women end up donating more than they recieve and even selling their kidneys [23, 24]. Women seem to be more willing than men to volunteer and take risks in living donation [25]. There is no conclusive evidence as to why women donate more and receive fewer kidneys [21]. Some studies that have analysed the reasons behind this disparity show that socioeconomic factors play an important role. Donating a kidney leads to economic loss at several levels depending on the conditions of each country [26, 27]. As a result, some studies have suggested that different income levels and work situations between men and women may influence this disparity [21]. Others point out that women may be driven to donation owing to ideological discourses that consider men the main providers of material resources within families $[28,29]$. The social context in which this research takes place, gender system, as a structuring of societies based on relations of privilege and power, leads to an unequal access to economic, social and symbolic resources [30]. Furthermore, healthcare field is highly feminised [31]. Within this framework, there are studies in the social sciences that provide an alternative explanation to altruism, which for years has been the basis for organ donation, showing that kidney donation by women may be explained as a form of social reproduction [32], or as a result of social pressure (economic dependence and care burdens) [24, 33-35].

Some studies specify that it is mostly mothers, followed by wives, that donate kidneys [36]. One metanalysis shows that the closer the relationship between people, the greater the tendency to donate [37]. Some studies highlight that the decision to donate a kidney should be seen in the context of the network of close family relationships [38] and that the moral roles of kinship and the ambiguities in family relationships influence the decision to donate within the family [23, 32, 37-40].

The aim of the study is to explore the experiences of two categories of women who donate their kidneys in the family context: women with biological kinship ties with the recipient (mothers, sisters) and women with social-cultural ties (wives) and examine whether there are similarities and differences in their experiences.

\section{Materials and methods Approach and design}

This study uses the method of hermeneutic phenomenology following the postulates of Heidegger [41]. Hermeneutic phenomenology explores lived experience in depth, with the goal of creating meaning and understanding [42]. This interpretive approach made it possible for us to capture the essence of the women donors' experiences during the kidney donation process.

We feel it is important to analyse living-donor kidney transplantation from a gender intersectional perspective since, as feminist theory proposes [43, 44], including the category of gender, as a social construction, provides us with a more complete level of analysis of the differences and inequalities in health between men and women.

Study manuscript is based on the consolidated criteria for reporting qualitative research (COREQ) [45] (see Table 1).

\section{Participants}

Study participants were adult women who donated kidneys to pre-dialysis recipients.

Inclusion criteria were female donors accepted for kidney donation in three kidney transplant units in Barcelona. Recipients had to be at least 18 years of age with chronic renal failure that had not begun dialysis treatment. This more restrictive inclusion criterion is important for the study authors since whether the recipient had or had not initiated dialysis could influence the experience of the women donors. Study was carried out between November 2017 and February 2020. Six researchers (five women and one man) participated in this study.

This study is part of a larger prospective study where donor-recipient pairs are selected and studied from the donor evaluation process to 6 months after surgery. A total of 10 participants agreed to participate in the study. Their characteristics are shown in Table 2. All the 
Table 1 Consolidated criteria for reporting qualitative studies (COREQ): 32-item checklist

\section{Domain Item TopicTopic \\ No \\ Guide Questions/Description}

\section{Research team and reflexivity}

Personal Characteristics:

\section{Interviewer/} facilitator

2 Credentials

3 Occupation

$4 \quad$ Gender

$5 \quad$ Experience and training

Relationship with participants:

6 Relationship established

\section{$7 \quad$ Participant} knowledge of the interviewer

8 Interviewer characteristics

Which author/s conducted the interview or focus group?

What were the researcher's credentials?

What was their occupation at the time of the study?

Was the researcher male or female?

What experience or training did the researcher have?

Was a relationship established prior to study commencement?

What did the participants know about the researcher?

What characteristics were reported about the interviewer/facilitator?

\section{Study design}

Theoretical framework:

9 Methodological orientation and Theory

Participant selection:

$\begin{array}{ll}10 & \text { Sampling } \\ 11 & \begin{array}{l}\text { Method of } \\ \text { approach }\end{array}\end{array}$

12 Sample size

13 Non-participation

Setting:

14 Setting of data collection

15 Presence of nonparticipants

16 Description of sample

Data collection:

17 Interview guide
What methodological orientation was stated to underpin the study?

How were participants selected?

How were participants approached?

How many participants were in the study?

How many people refused to participate or dropped out? Reasons?

Where was the data collected?

Was anyone else present besides the participants and researchers?

What are the important characteristics of the sample?

Were questions, prompts, guides provided by the authors? Was it pilot tested?
Page 3: "One of the women authors (LR), who is not part of transplant team, contacted each of participants and went to their homes to conduct the interviews".

N/A

N/A

Page 3: "Six researchers (five women and one man) participated in this study".

Page 4: "Four of the researchers (LRM, SB, EMR, MSC) had previous experience in qualitative study designs".

Page 3: "One person in charge from each kidney transplant unit identified participants who met inclusion criteria and informed them of the study."

Page 3: "One of the women authors (LR), who is not part of transplant team, contacted each of participants".

Page 12: "Participants received verbal and written information about main researcher and study aims".

Page 2: "This study uses the method of hermeneutic phenomenology following the postulates of Heidegger $[40]^{\prime \prime}$.

Page 3: "A purposive sample was used".

Page 3: "One person in charge from each kidney transplant unit identified participants who met inclusion criteria and informed them of the study. Once they had given verbal consent, one of the women authors (LR), who is not part of transplant team, contacted each of participants".

Page 3: "A total of 10 participants agreed to participate in the study. All the participants had biological kinship (30\% mothers or sisters) or sociocultural (70\% wives) ties".

Not aplicable-All who contacted participated in the study.

Page 3: "one of the women authors (LR), who is not part of transplant team, contacted each of participants and went to their homes to conduct the interviews and sign the written consent".

Page 3: "One or more individual interviews were held for each participant, before and after the donation, depending on the stage of donation process the women were in during the period of the study".

Table 2

Page 3: "Interview script arose from a review of the literature related to the purpose of the study, as well as from the work done with fellow kidney transplant professionals. Script was previously tested with three female donors that had 
Table 1 Consolidated criteria for reporting qualitative studies (COREQ): 32-item checklist (Continued)

\begin{tabular}{|c|c|c|c|c|}
\hline Domain & $\begin{array}{l}\text { Item } \\
\text { No }\end{array}$ & TopicTopic & Guide Questions/Description & Reported on Page No. \\
\hline & & & & already gone through the kidney donation process". \\
\hline & 18 & Repeat interviews & $\begin{array}{l}\text { Were repeat interviews carried out? If yes, how } \\
\text { many? }\end{array}$ & $\begin{array}{l}\text { Page 3: "Data saturation was achieved in the } 17 \text { interviews } \\
\text { conducted with } 10 \text { participants." } \\
\text { Page 3: "One or more individual interviews were held for } \\
\text { each participant, before and after the donation, depending } \\
\text { on the stage of donation process the women were in } \\
\text { during the period of the study". }\end{array}$ \\
\hline & 19 & $\begin{array}{l}\text { Audio/visual } \\
\text { recording }\end{array}$ & $\begin{array}{l}\text { Did the research use audio or visual recording } \\
\text { to collect the data? }\end{array}$ & $\begin{array}{l}\text { Page 3: "Interviews were recorded and transcribed } \\
\text { verbatim". }\end{array}$ \\
\hline & 20 & Field notes & $\begin{array}{l}\text { Were field notes made during and/or after the } \\
\text { interview or focus group? }\end{array}$ & $\begin{array}{l}\text { Page 3: "Field notes were taken in each interview that were } \\
\text { retrieved during the data analysis stage". }\end{array}$ \\
\hline & 21 & Duration & $\begin{array}{l}\text { What was the duration of the interviews or } \\
\text { focus group? }\end{array}$ & $\begin{array}{l}\text { Page 3: "Average length of the interviews was } 36 \mathrm{~min} \\
\text { (between } 26 \text { and } 53 \mathrm{~min} \text { )". }\end{array}$ \\
\hline & 22 & Data saturation & Was data saturation discussed? & $\begin{array}{l}\text { Page 3: "Data saturation was achieved in the } 17 \text { interviews } \\
\text { conducted with } 10 \text { participants." }\end{array}$ \\
\hline & 23 & $\begin{array}{l}\text { Transcripts } \\
\text { returned }\end{array}$ & $\begin{array}{l}\text { Were transcripts returned to participants for } \\
\text { comment and/or correction? }\end{array}$ & $\begin{array}{l}\text { Page 3: "Participants were given the interview transcript for } \\
\text { comment". }\end{array}$ \\
\hline \multicolumn{5}{|c|}{ Analysis and fidings } \\
\hline \multicolumn{5}{|c|}{ Data analysis: } \\
\hline & 24 & $\begin{array}{l}\text { Number of data } \\
\text { coders }\end{array}$ & How many data coders coded the data? & $\begin{array}{l}\text { Page 4: "Data analysis was reviewed by two team } \\
\text { members". }\end{array}$ \\
\hline & 25 & $\begin{array}{l}\text { Description of the } \\
\text { coding tree }\end{array}$ & $\begin{array}{l}\text { Did authors provide a description of the coding } \\
\text { tree? }\end{array}$ & N/A \\
\hline & 26 & $\begin{array}{l}\text { Derivation of } \\
\text { themes }\end{array}$ & $\begin{array}{l}\text { Were themes identified in advance or derived } \\
\text { from the data? }\end{array}$ & $\begin{array}{l}\text { Page 3: (Data Analysis) "We then proceeded to generate } \\
\text { initial codes and organise the topics and sub-topics that } \\
\text { arose inductively". }\end{array}$ \\
\hline & 27 & Software & $\begin{array}{l}\text { What software, if applicable, was used to } \\
\text { manage the data? }\end{array}$ & N/A \\
\hline & 28 & $\begin{array}{l}\text { Participant } \\
\text { checking }\end{array}$ & $\begin{array}{l}\text { Did participants provide feedback on the } \\
\text { findings? }\end{array}$ & $\begin{array}{l}\text { Not applicable as participants did not provide feedback on } \\
\text { the data/findings. }\end{array}$ \\
\hline \multirow[t]{4}{*}{ Reporting } & 29 & $\begin{array}{l}\text { Quotations } \\
\text { presented }\end{array}$ & $\begin{array}{l}\text { Were participant quotations presented to } \\
\text { illustrate the themes / findings? Was each } \\
\text { quotation identified? }\end{array}$ & $\begin{array}{l}\text { Page 4-9 (Results): Quotations are presented throughout } \\
\text { the text alongside interpretations. }\end{array}$ \\
\hline & 30 & $\begin{array}{l}\text { Data and findings } \\
\text { consistent }\end{array}$ & $\begin{array}{l}\text { Was there consistency between the data } \\
\text { presented and the findings? }\end{array}$ & Page 4-11 (Results and Discussion) \\
\hline & 31 & $\begin{array}{l}\text { Clarity of major } \\
\text { themes }\end{array}$ & $\begin{array}{l}\text { Were major themes clearly presented in the } \\
\text { findings? }\end{array}$ & Page 4-9 (Results) \\
\hline & 32 & $\begin{array}{l}\text { Clarity of minor } \\
\text { themes }\end{array}$ & $\begin{array}{l}\text { Is there a description of diverse cases or } \\
\text { discussion of minor themes? }\end{array}$ & Page 4-11 (Results and Discussion) \\
\hline
\end{tabular}

From: Tong A, Sainsbury P \& Craig J. Consolidated criteria for reporting qualitative research (COREQ): a 32-item checklist for interviews and focus groups Qual Assur Health Care. 2007;19(6):349-357

participants had biological kinship (30\% mothers or sisters) or sociocultural (70\% wives) ties.

\section{Data collection}

Data were obtained through semi-structured in-depth interviews. Interview script arose from a review of the literature related to the purpose of the study, as well as from the work done with fellow kidney transplant professionals. Script was previously tested with three female donors that had already gone through the kidney donation process.
A purposive sample was used. One person in charge from each kidney transplant unit identified participants who met inclusion criteria and informed them of the study. Once they had given verbal consent, one of the women authors (LR), who is not part of transplant team, contacted each of participants and went to their homes to conduct the interviews and sign the written consent. One or more individual interviews were held for each participant, before and after the donation, depending on the stage of donation process the women were in during the period of the study. Average length of the interviews was $36 \mathrm{~min}$ (between 26 and $53 \mathrm{~min}$ ). Interviews were 
Table 2 Characteristics of the participants

\begin{tabular}{llll}
\hline Participant & Age & Relationship to the recipient s & Sex of the recipient \\
\hline D1 & 71 & Wife & Man \\
D2 & 64 & Wife & Man \\
D3 & 74 & Wife & Man \\
D4 & 66 & Wife & Man \\
D5 & 52 & Wife & Man \\
D6 & 57 & Wife & Woman \\
D7 & 44 & Mother & Man \\
D8 & 58 & Mother & Man \\
D9 & 60 & Mother & Woman \\
D10 & 70 & Sister &
\end{tabular}

recorded and transcribed verbatim, and field notes were taken in each interview that were retrieved during the data analysis stage. Participants were given the interview transcript for comment. Data saturation was achieved in the 17 interviews conducted with 10 participants.

\section{Data analysis}

A thematic analysis [46] was performed in order to understand meanings produced by the stories of the women that donate a kidney to a relative. Interviews were first read and re-read while both listening to audio recording so as not to miss any subtle information and writing down notes in the margins [47]. We then proceeded to generate initial codes and organise topics and sub-topics that arose inductively. All the relevant data for each topic were collected, and the link between these and the research objectives was verified. Next step in the analysis process involved verifying and contrasting findings by returning to original text and reworking topics that would enable us to understand meanings of the women kidney donors. Data analysis was reviewed by two team members. Four of the researchers (LRM, SB, EMR, MSC) had previous experience in qualitative study designs.

\section{Results}

All women donated their kidneys to men, except for two biologically related donations that went from mother to daughter and between sisters (see Table 2).

Through thematic analysis we identified five topics:

\section{THEME 1: convinced decision-making}

Women's decision to donate a kidney to a relative was taken to improve life and health of the recipient. Participants had witnessed recipient's illness from the beginning or for at least 10 years. Seeing recipient's health deteriorate and limitations appear in his/her life influenced the decision to donate. All donations were before the recipient needed dialysis. Making donation to avoid dialysis treatment was one of participants motivations.

Decision was also easy and clear. Women comment that although they can share situation with family and friends, decision was intimate and personal.

"I went for it! I said: First me, and if that isn't possible, we'll look for someone". (...) "I decided 5 years ago and I haven't regretted it once". (D5_1).

All the participants volunteered to be donors, although they had never considered being organ donors before. In no case did the recipient ask them. According to interviews, the decision to donate a kidney was made free of external pressure and internal doubts.

\section{"I was very clear about it. I never felt any obligation to donate" (D9_1).}

Women stated that they felt convinced and confident in themselves and the decision they had made. After the donation, at no time did they regret the decision to donate and would do so again.

\section{THEME 2: not worrying about their health}

Women donors perceived their good health prior to donation, which was confirmed in the results of examinations and physical tests during the evaluation process, which showed they were healthy and could donate a kidney.

Participants considered that their health after the post-surgery recovery period would be the same and they were not worried about possible complications or their long-term health. When asked about their future health, they said they were not afraid of changes or alterations in their health and trusted the good results of kidney transplantation and the health systems and its professionals. 
"I see my health after the donation as the same as now, I don't notice any differences" (D4_1).

They were also not worried about donating an organ as they had no interest in keeping their body intact.

Once the donation was made, neither long-term health nor organ loss concerns appeared in the women donors.

The only change in participants' health was aimed at maintaining their good health in order to be in the best condition for the donation. Since they were accepted as donors, they recognised that they took greater care of themselves, in sense of changing unhealthy habits: they improved some eating habits or gave up drinking alcohol or smoking. In every case we saw that the women donors increased their physical exercise, increasing the frequency or starting a new sports.

\section{THEME 3: showing an optimistic and positive attitude}

Participants showed an optimistic and positive attitude about many aspects of donation. They acknowledged that the evaluation period for being a kidney donor was intense and long and sometimes difficult to reconcile with their work and personal obligations, but it did not become a burden.

They went to surgery with a calm and confident attitude that there would be no complications either for them or for the recipient. They thought that surgery would be successful and that the donation would go well. Despite knowing about the possible complications in receiving the organ, they did not think about recipient rejection.

"There's no reason why something should happen. Everything will remain the same". (D7_1).

Dealing with health professionals during the donation process and the good overall results of living-donor kidney transplantation helped them maintain a positive attitude.

Women donors maintained a positive attitude before and after the donation.

\section{THEME 4: donation is not a heroic act}

All participants agreed that donating a kidney is not a heroic act. They refused to believe that donating an organ was so important. Neither before nor after the donation, did they see it as something that should be praised and required great recognition.

"People say: 'Oh, what a great thing you did'. I don't! I see it as completely normal. I don't see it as making a great sacrifice or as a big deal, no. I see it as normal". (D5_1).
"People make a big deal, a very big deal about it. And I think: it's not that big a deal" (D6_1).

Before kidney donation, study participants had played an important supporting and caring role with family.

"I am family mainstay because I've had to keep things going for a long time. I looked after my father, then my mother, my uncle and aunt. I've always had to be there. And in my house everyone trusts me a little". (D9_1).

There is a difference between donors with biological kinship ties and those that have a sociocultural relationship with the recipient. Former saw donation as "a naturalization thing". Many used the term 'normal' in their accounts: donation within the family is conceived as a normal.

"When they talked about the need to a transplant, her father and I went immediately to do the tests and it turned out that I could give it to her. (...) I see that she is happy [and thinks] 'Mother can do it'. In the family, you know? (...) I said to her: if all goes well, I gave you life and now I will give it back to you". (D3_1).

In contrast, for the donor wives, the situation they experienced with the progression of their husbands' illness and its consequences in their lives influenced donate decision.

"The situation takes you there. You enter a world that you don't know how you got there and you have to continue" (D9_1).

"You never thought you would be in a situation where perhaps one day you'd have to donate an organ" (D6_1).

"Many people say: 'Oh, you are really brave! I don't know if I would do it'. That's not the point. You have to find yourself in the situation and then decide" (D6_1).

Wives also said that donation was seen as "doing what is expected", both from their own and others' perspective. In the above quotes we can see how the women were convinced in their decision. Within the family, the news of this decision that they made freely and clearly was not experienced as a conflict but was accepted.

"Mum, you have done a good thing" (D2_1). 
"I think it was a good deed and I did it for him" (D2_2).

"I did a good thing" (D6_2).

The donation of the wives makes sense and is part of the moral relationship of couple.

"I think I should do it. I should do it for him. He's my partner and he's the person I will live with". (D7_1).

"He would also do it". (D10_1).

Most of wives said that gender-differentiated education influenced their decision to give:

"I don't think it's a genetic thing, but rather that they educate us in the values of caring for others and that makes us more willing to do it”. (D6_3).

"Women see beyond, think more of others". (D9_1).

\section{THEME 5: personal benefits: avoiding carer role and}

\section{protecting the children}

Experiencing the donation as a personal benefit was found in the group of donor wives. It meant that participants not only experienced satisfaction in helping a loved one who needed a kidney, but also emotional and personal benefits for themselves:

"When you have the chance to do something for somebody, I wouldn't feel good not doing it!". (D6_1).

"I feel bad if I see that he's feeling bad". (D7_1).

"There's a part that wants him to be well, but there's also a selfish part that thinks that if he isn't well I won't be either. Our life would change a lot (...) I want you to be well so that our life being well is extended as long as possible". (D6_1).

Personal benefits experienced by wives was in no way related to the type of relationship that would arise after donation, since the donor wives expected that the relationship with the recipient would remain the same, unchanged. And so, it was for the women who made the donation; they claimed that the relationship with their husbands had not changed.

Wives were well aware of prognosis of chronic kidney disease and knew that without a kidney transplant their husbands would end up on dialysis, which would greatly affect the quality of life and that of their families.
Donating the kidney to their partners would mean avoiding taking on carer role for their husbands.

"If he gets sick, what? I don't want to take care of a sick person” (D2_1).

"I don't want to have two kidneys and have to take care of him" (D6_3).

Another personal benefit that women with a sociocultural relationship mentioned was that they felt satisfied in having been accepted as donors to their husbands since this ruled out their children being possible donors. Donating the kidney to their husband protected their children from becoming kidney donors for their parents.

"My son found it very difficult to understand. He said to me: 'I'll give it to dad'. And I said to him: 'No! You will not give it to him'. No! I didn't want it to be him. No!" (D8_1).

"The first thing my children said was: 'Mum, you are very old, we'll give it to dad'. And I said no! I'd prefer to give it to him myself. We're not going to live as long as them. And they need both kidneys, you never know what life may bring ...." (D10_1).

\section{Discussion/Conclusion}

This study provides knowledge from a gender perspective on the similarities and differences between the experiences of women who donated a kidney to relatives with biological kinship ties (children and siblings) and women who donated a kidney to their husbands.

The main reasons why they decided to donate a kidney are the same for all the women. All of them witnessed the recipient's illness. The desire to improve their health and prevent them from entering dialysis were key to their decision-making. Concern for the recipient health and the wish to improve his/her quality of life as well as avoid complications or even death were reported in previous studies [37, 48-51]. Participants decisions in our study were made with ease and conviction, in line with previous studies $[48,49]$.

With regards to the donor's health, they were aware of their good health and, according to Manera et al. [52] this is important when deciding to donate a kidney. Participants were optimistic and confident about donation and their future health. Gill [53] found that hope and optimism are coping mechanisms that help with the stress triggered by living-donor kidney transplantation. Acording with the literature $[48,54,55]$ the donors were more worried about recipient health that their own short- and long-term health. Thus, healthcare 
professionals need to provide more information on the risks that donors run.

Women expressed no desire to keep their body intact. Some studies $[48,56,57]$ find that after donation donors do not experience any sense of loss with regards to donated organ.

Like other studies $[49,58,59]$, participants did not consider the donation to be a heroic act. One contribution of our study was to find differences between women when delving more deeply into this aspect. Moreover, as other studies [38,60], participants with biological kinship bonds said that they saw their donation as a 'natural thing', as the natural consequence of family bonds, as a matter of course within the family. We understand this normality as a social construction that is framed in a certain context [61]. In this case the donation takes place within the family, which is where, in Sahlins [62] terms, mutuality of being is developed, conditioned by values and moral obligations that bind people [63].

Wives decision needs to be understood within the network of conjugal relations, but it is also influenced by gender roles constructed in the social context in which they live. Women who donated a kidney to their husbands had not previously thought of being organ donors, and it was the context of their spouse's illness and the moral roles within the couple that influenced their decision. Ummel and Achille [56] argue that genetically or emotionally related donors are driven to donate their kidney due to their moral obligations within the family.

One of the study's findings, consistent with others [28, $32]$, is that the gender role could have influenced women to offer themselves as donors for their husbands. All the women participants had previously provided care and assistance to members of their family (children, parents, mother or father-in-law). Subsequently, these women not only donated their organ, but also took care of recipient at home after surgery. We can compare this care service with other types of care work, such as caring for the elderly or sick relatives, which is undertaken disproportionately and in a "normalized manner" by women [64] and that, in consequence, affects their health and quality of life $[65,66]$. It is not possible to generalise from our small sample but, as Zeiler [33] states, it would be an ethical concern if gender disparity in living-donors were explained by traditional roles that force women to care for the sick members of their family. Wife participants of our study were aware that gender discourse and education influenced their decision to donate a kidney to their husband. According to our findings, genderdifferentiated education may be an ally for organ donation.

However, wives stated that the donation brought them personal benefits for themselves. They experienced emotional benefits that went beyond improving the recipient's life and that were related to mitigating feelings of sadness and frustration they experienced on seeing their husband's suffering and not doing anything for him. These feelings of frustration have been observed in people who have been rejected as kidney donors [67].

Wives knew that without the kidney transplant the autonomy of their husbands would be more limited and that they would need care and assistance. Kidney donation meant they could avoid taking on the role of carer for their husbands. This act of empowerment and control over their lives coincides with De Groot's study [68], where women donors thought that the transplant allowed recipient to be less dependent and more involved in family life, thus improving donors' quality of life.

This research we found that, unlike other studies where women could donate because of structural and economic pressures $[29,34,69]$, wives donated their kidneys as a personal benefit and as a form of empowerment. It is essential that healthcare professionals pay attention to these aspects in order to better accompany the women's decision-making with regards to kidney donation.

To finalize it is important to highlight that has not been established in the literature. With the decision to donate, women who donate to their husbands protect their children by ruling them out as possible donors. This is how they play a protective role towards the younger members of the family.

The study has some limitations. All the participants volunteered for the donation. To learn more about donation and gender it might be interesting to delve more deeply into the experiences of women who did not volunteer to donate a kidney to a family member with kidney failure and learn about their thoughts and motivations. At the same time, men's motivations to donate should also be explored. Furthermore, we cannot generalize our data to donors in countries where access to kidney replacement treatment is very different from Spain. Future research is required to clarify all the factors that could play a key role in gender disparity in living-donor kidney transplantation.

\section{Conclusion}

Women donate their kidneys with clarity, without concern for their own health, with an optimistic and positive attitude and without believing that they are committing a heroic deed. Women with biological kinship ties to recipient see the donation as a 'naturalization thing'. In contrast, wives donate conditioned by gender roles but also do it as a form of empowerment and as a personal benefit: they donate in order to avoid taking on carer role for their husband and as a way of protecting their children. 
Study examines the gender gap in donation and provides new insights into and a better understanding of the life of women who donate a kidney.

The study's findings expand the conception of kidney donation as solely altruistic and can help professionals pay attention to the complexity that women living kidney donors face.

\section{Acknowledgements}

Authors would like to thank nephrology and transplant teams who helped us in recruiting participants and donors who generously shared their experiences with us.

\section{Authors' contributions}

LR: Study design, data collection, data analysis, revision and final approval of the manuscript. SB: Study design, data analysis, critical review and final approval of the manuscript. EM, EO and LP: Critical review and final approval of the manuscript. MS: Study design, critical review and final approval of the manuscript.

\section{Funding}

This study has not received funding.

\section{Availability of data and materials}

The datasets generated and/or analysed during the current study are not publicly available to protect the identification of the participants but are available from the corresponding author on reasonable request.

\section{Ethics approval and consent to participate}

Ethics Committee approval of three kidney transplant units was obtained (Clinic Hospital of Barcelona, Germans Trias and Pujol Hospital and Hospital of Mar of Barcelona). Study follows the principles laid out in the Declaration of Helsinki [70]. Participants received verbal and written information about main researcher and study aims. Moreover, they were informed that their participation was voluntary and that the confidentiality of the information was guaranteed. All participants signed the written informed consent.

\section{Consent for publication}

Not applicable.

\section{Competing interests}

The authors declare that they have no competing interests.

\section{Author details}

${ }^{1}$ Department of Nephrology, Consorci Hospitalari de Vic, Vic, Catalunya, Spain. ${ }^{2}$ Research group on Methodology, Methods, Models and Outcomes of Health and Social Sciences (M3O), Faculty of Health Science and Welfare, Centre for Health and Social Care Research (CESS), University of Vic-Central University of Catalonia (UVIC-UCC), Vic, Spain. ${ }^{3}$ Department of Anthropology, Philosophy and Social Work in the University of Rovira i Virgili (URV), Tarragona, Catalunya, Spain. ${ }^{4}$ Department of Nursing Management, Parc Taulí Health Corporation Consortium, Sabadell, Catalunya, Spain.

Received: 11 October 2020 Accepted: 12 January 2021

Published online: 16 February 2021

\section{References}

1. Bikbov B, Purcell CA, Levey AS, Smith M, Abdoli A, Abebe M, et al. Global, regional, and national burden of chronic kidney disease, 1990-2017: a systematic analysis for the Global Burden of Disease Study 2017. The Lancet. 2020;395(10225):709-33.

2. Liyanage T, Ninomiya T, Jha V, Neal B, Patrice HM, Okpechi I, et al. Worldwide access to treatment for end-stage kidney disease: a systematic review. Lancet. 2015;385(9981):1975-82.

3. Jay $C L$, Dean $P G$, Helmick RA, Stegall MD. Reassessing preemptive kidney transplantation in the United States: are we making progress? Transplant. 2016;100(5):1120.

4. Global Observatory on Donation and Transplantation. International report on organ donation and transplantation activities executive summary 2017
[Internet]. World Health Organization; 2019 [cited 2020 May 31]. Available from: http://www.transplant-observatory.org/wp-content/uploads/2019/11/ glorep2017.pdf.

5. Lentine KL, Lam NN, Segev DL. Risks of living kidney donation: current state of knowledge on outcomes important to donors. Am Soc Nephrol. 2019; 14(4):597-608

6. Mjoen G, Hallan S, Hartmann A, Foss A, Midtvedt K, Øyen O, et al. Longterm risks for kidney donors. Kidney Int. 2014;86(1):162-7.

7. Muzaale $A D$, Massie $A B$, Wang $M C$, et al. Risk of end-stage renal disease following live kidney donation. Jama. 2014;311(6):579-86.

8. Grams ME, Sang Y, Levey AS, Matsushita K, Ballew S, Chang AR, et al. Kidney-failure risk projection for the living kidney-donor candidate. N Engl J Med. 2016;374(5):411-21.

9. Jacobs CL, Gross CR, Messersmith EE, Hong BA, Gillespie BW, Hill-Callahan P, et al. Emotional and financial experiences of kidney donors over the past 50 years: the RELIVE study. Clin J Am Soc Nephrol. 2015;10(12):2221-31.

10. Przech S, Garg AX, Arnold JB, Barnieh L, Cuerden MS, Dipchand C, et al. Financial costs incurred by living kidney donors: a prospective cohort study. I Am Soc Nephrol. 2018;29(12):2847-57.

11. Rota-Musoll L, Subirana-Casacuberta M, Oriol-Vila E, Homs-Del Valle M, Molina-Robles E, Brigidi S. The experience of donating and receiving a kidney: a systematic review of qualitative studies. J Ren Care. . https://doi. org/10.1111/jorc.12309.

12. Hill NR, Fatoba ST, Oke JL, Hirst JA, O'Callaghan CA, Lasserson DS, et al. Global prevalence of chronic kidney disease-a systematic review and metaanalysis. PloS one. 2016;11(7):e0158765.

13. Carrero JJ, Hecking M, Chesnaye NC, Jager KJ. Sex and gender disparities in the epidemiology and outcomes of chronic kidney disease. Nat Rev Nephrol. 2018;14(3):151.

14. Brar A, Markell M. Impact of gender and gender disparities in patients with kidney disease. Curr Opin Nephrol Hypertens. 2019;28(2):178-82.

15. Halle MP, Takongue C, Kengne AP, Kaze FF, Ngu KB. Epidemiological profile of patients with end stage renal disease in a referral hospital in Cameroon. BMC Nephrol. 2015;16(1):59.

16. Saran R, Robinson B, Abbott KC. US renal data system 2016 annual data report: epidemiology of kidney disease in the United States. Am J Kidney Dis. 2017;69(3):A7-8.

17. Carrero JJ, Hecking M, Ulasi I, Sola L, Thomas B. Chronic kidney disease, gender, and access to care: a global perspective. Semin Nephrol. 2017;37(3): 296-308.

18. Salter ML, McAdams-Demarco MA, Law A, Kamil RJ, Meoni LA, Jaar BG, et al. Age and sex disparities in discussions about kidney transplantation in adults undergoing dialysis. J Am Geriatr Soc. 2014;62(5):843-9.

19. Monson RS, Kemerley P, Walczak D, Benedetti E, Oberholzer J, Danielson KK Disparities in completion rates of the medical pre-renal transplant evaluation by race/ethnicity and gender. Transplant. 2015;99(1):236.

20. Jindal RM, Ryan JJ, Sajjad Murthy MH, Baines LS. Kidney transplantation and gender disparity. Am J Nephrol. 2005;25(5):474-83.

21. Piccoli GB, Alrukhaimi M, Liu ZH, Zakharova E, Levin A. What we do and do not know about women and kidney diseases; questions unanswered and answers unquestioned: reflection on World Kidney Day and International Woman's Day. BMC Nephrol. 2018;19(1):66.

22. Domínguez-Gil B, Matesanz R. Newsletter Transplant. International Figures on Donation and Transplantation 2016. Eur Dir Qual Med Healthc Counc Eur. 2017;22.

23. Simmons RG, Marine SK, Simmons RL. Gift of life: The effect of organ transplantation on individual, family, and societal dynamics. New Jersey: Transaction Publishers; 1987

24. Scheper-Hughes $\mathrm{N}$. The tyranny of the gift: sacrificial violence in living donor transplants. Am J Transplant. 2007;7(3):507-11.

25. Steinman JL. Gender disparity in organ donation. Gend Med. 2006;3(4): 246-52.

26. Hanson CS, Ralph AF, Manera KE, Gill JS, Kanellis J, Wong G, et al. The lived experience of "being evaluated" for organ donation: focus groups with living kidney donors. Clin J Am Soc Nephrol. 2017;12(11):1852-61.

27. McGrath $P$, Holewa $H$. It's a regional thing': financial impact of renal transplantation on live donors. Rural Remote Health. 2012b:12(4):1-10.

28. Oien CM, Reisæter AV, Leivestad T, Pfeffer P, Fauchald P, Os I. Gender imbalance among donors in living kidney transplantation: the Norwegian experience. Nephrol Dial Transplant. 2005;20(4):783-9. 
29. Rasmussen S, Paneru P, Shrestha K, Shrestha PC. Gender bias and organ transplantation in Nepal. HIMALAYA J Associ Nepal Himalayan Stud. 2016; 36(2):8.

30. Scott JW. El género, una categoría útil para el análisis histórico. México: PUEG; 1986

31. Esteban ML. Los cuidados, un concepto central en la teoría feminista: aportaciones, riesgos y diálogos con la antropología. Quaderns-e Inst Català Antropol. 2017;22(2):33-48

32. Crowley-Matoka M, Hamdy SF. Gendering the gift of life: family politics and kidney donation in Egypt and Mexico. Med Anthropol. 2016;35(1):31-44.

33. Zeiler K. Just love in live organ donation. Med Health Care Philos. 2009; 12(3):323-31.

34. Shaw R. Live kidney donation as body work. Crit Soc Policy. 2014;34(4):495-514.

35. Shaw RM. Altruism, solidarity and affect in live kidney donation and breastmilk sharing. Sociol Health IIIn. 2019;41(3):553-66.

36. Godara S, Jeswani J. Women donate, men receive: gender disparity among renal donors. SJKDT. 2019;30(6):1439.

37. Ummel D, Achille M, Mekkelholt J. Donors and recipients of living kidney donation: a qualitative metasummary of their experiences. J Transplant. 2011. https://doi.org/10.1155/2011/626501.

38. Halverson CM, Crowley-Matoka M, Ross LF. Unspoken ambivalence in kinship obligation in living donation. Prog Transplant. 2018;28(3):250-5.

39. Heinemann LL. For the sake of others: reciprocal webs of obligation and the pursuit of transplantation as a caring act. Med Anthropol Q. 2014;28(1):66-84

40. Messersmith EE, Gross CR, Beil CA, Gillespie BW, Jacobs C, Taler SJ, et al. Satisfaction with life among living kidney donors: a RELIVE study of longterm donor outcomes. Transplantation. 2014:98(12):1294.

41. Walters AJ. The phenomenological movement: implications for nursing research. J Adv Nurs. 1995;22(4):791-9.

42. Wilson HS, Hutchinson SA. Triangulation of qualitative methods: Heideggerian hermeneutics and grounded theory. Qual Health Res. 1991; 1(2):263-76.

43. Moore HL. Antropología y feminismo. Universitat de València;1991.

44. Collins PH. Gender, black feminism, and black political economy. Ann Am Acad Pol Soc Sci. 2000;568(1):41-53.

45. Tong A, Sainsbury P, Craig J. Consolidated criteria for reporting qualitative research (COREQ): a 32-item checklist for interviews and focus groups. Qual Assur Health Care. 2007:19(6):349-57.

46. Braun V, Clarke V. Using thematic analysis in psychology. Qual Res Psych. 2006:3:77-101.

47. Creswell JW, Poth CN. Qualitative Inquiry \& Research Design Choosing among Five Approaches. Thousand Oaks, CA: Sage Publications; 2017.

48. Andersen MH, Mathisen L, Øyen O, Wahl AK, Hanestad BR, Fosse E. Living donors' experiences 1 wk after donating a kidney. Clin Transpl. 2005;19(1): 90-6.

49. McGrath P, Pun P, Holewa H. Decision-making for living kidney donors: an instinctual response to suffering and death. Mortality. 2012;17(3):201-20.

50. Farahani ZB, Esmaeili M, Salsali M, Nayeri ND. Factors affecting iranian family donors'motivation for kidney donation. Acta Med Med. 2016;32:1067-73.

51. Meyer KB, Bjørk IT, Wahl AK, Lennerling A, Andersen MH. Long-term experiences of Norwegian live kidney donors: qualitative in-depth interviews. BMJ Open. 2017;7(2):e014072.

52. Manera KE, Hanson CS, Chapman JR, Kanellis J, Gill J, Craig JC, et al. Expectations and experiences of follow-up and self-care after living kidney donation: a focus group study. Transplant. 2017:101(10):2627-35.

53. Gill P. Stressors and coping mechanisms in live-related renal transplantation. J Clin Nurs. 2012;21(11-12):1622-31.

54. Bertelsen KH, Rasmussen K, Ludvigsen MS, Finderup J. Experiences of recipients and living donors the first three days after kidney transplantation. J Ren Care. 2015;41(3):195-201.

55. Agerskov H, Ludvigsen MS, Bistrup C, Pedersen BD. Living kidney donors' experiences while undergoing evaluation for donation: a qualitative study. J Clin Nurs. 2015;24(15-16):2258-67.

56. Ummel D, Achille M. Transplant trajectory and relational experience within living kidney dyads. Qual Health Res. 2016;26(2):194-203.

57. Williams AM, Colefax L, O'Driscoll CT, Dawson S. An exploration of experiences of living renal donors following donation. Nephrol Nurs J. 2009; 36(4):423-7.

58. Gill P, Lowes L. Gift exchange and organ donation: donor and recipient experiences of live related kidney transplantation. Int J Nurs Stud. 2008; 45(11):1607-17.
59. Davis LA, Grogan TM, Cox J, Weng FL. Inter-and intrapersonal barriers to living donor kidney transplant among black recipients and donors. J Racial Ethn Health Disparities. 2017;4(4):671-9.

60. Agerskov H, Thiesson H, Specht K, Pedersen B. Parents' experiences of donation to their child before kidney transplantation: a qualitative study. J Clin Nurs. 2019;28(9-10):1482-90.

61. Benedict R \& Mécréant L. Le chrysanthème et le sabre. P. Picquier; 1991.

62. Sahlins M. What kinship is-and is not: University of Chicago Press; 2013.

63. McKinley R. The philosophy of kinship: A reply to Schneider's Critique of the Study of Kinship. The cultural analysis of kinship: the legacy of David M. Schneider. Chicago: University of Illinois Press; 2001. p. 131-7.

64. Comas d'Argemir D. Mujeres, familia y estado del bienestar. Perspectivas feministas desde la antropología social. Ariel; 2000:187-204.

65. Adelman RD, Tmanova LL, Delgado D, Dion S, Lachs MS. Caregiver burden: a clinical review. Jama. 2014;311(10):1052-60.

66. González L, Real J, Borrás A, Martínez-Sánchez JM, Rodrigo-Baños V, NavarroRubio MD. Associations between informal care, disease, and risk factors: a Spanish country-wide population-based study. J Public Health Policy. 2016; 37(2):173-89.

67. Agerskov H, Bistrup C, Ludvigsen MS, Pedersen BD. Experiences of living kidney donors during the donation process. J Ren Care. 2018;44(2):96-105.

68. De Groot IB, Schipper K, van Dijk S, van der Boog PJ, Stiggelbout AM, Baranski $A G$, et al. Decision making around living and deceased donor kidney transplantation: a qualitative study exploring the importance of expected relationship changes. BMC Nephrol. 2012;13(1):103.

69. Zimmerman D, Donnelly S, Miller J, Stewart D, Albert SE. Gender disparity in living renal transplant donation. Am J Kidney Dis. 2000;36(3):534-40.

70. World Medical Association [Internet]. Declaration of Helsinki: Ethical principles for Medical research involving human subjects [cited 2020 may 20]. Available from: https://www.wma.net/policies-post/wma-declaration-ofhelsinki-ethical-principles-for-medical-research-involving-human-subjects/.

\section{Publisher's Note}

Springer Nature remains neutral with regard to jurisdictional claims in published maps and institutional affiliations.

Ready to submit your research? Choose BMC and benefit from:

- fast, convenient online submission

- thorough peer review by experienced researchers in your field

- rapid publication on acceptance

- support for research data, including large and complex data types

- gold Open Access which fosters wider collaboration and increased citations

- maximum visibility for your research: over $100 \mathrm{M}$ website views per year

At $\mathrm{BMC}$, research is always in progress.

Learn more biomedcentral.com/submissions 